David Aldridge

The Case for Humanism in Religious Education, Journal of Beliefs and Values, vol. 36, no. 1 (2015)

DOI: 10.1080/13617672.2015.1014650

This version is available: https://radar.brookes.ac.uk/radar/items/6a2de016-f3d3-44ad-936d-

ab9835dc55f9/1/

Available on RADAR: 22.11.2016

Copyright ( $)$ and Moral Rights are retained by the author(s) and/ or other copyright owners. A copy can be downloaded for personal non-commercial research or study, without prior permission or charge. This item cannot be reproduced or quoted extensively from without first obtaining permission in writing from the copyright holder(s). The content must not be changed in any way or sold commercially in any format or medium without the formal permission of the copyright holders.

This document is the postprint version. Some differences between the published version and this version may remain and you are advised to consult the published version if you wish to cite from it. 


\title{
The Case for Humanism in Religious Education
}

\begin{abstract}
A dialogic approach to religious education is advanced in which subject matter emerges or transforms in the educational event. An example of religious dialogue is considered, through which it is demonstrated that religious education, in order to be considered educational, must take seriously the possibility of the transformation of its subject matter. Approaches to religious education which attempt to restrict in advance the contribution of Humanism or other non-religious standpoints do not take seriously the possibility of this transformation, and thus foreclose the possibilities for educational dialogue. Some objections to Humanism in religious education are then considered, and a bullet is bitten.
\end{abstract}

Keywords: Humanism, secular education, hermeneutics, dialogue, non-religious worldviews

\section{A Dialogic Approach to Religious Education}

The case for Humanism in religious education is here advanced in accordance with what I will call a hermeneutic or ontologically dialogic understanding of the endeavour of RE. The term 'ontological' here denotes that learning has the character of a dialogue, distinguishing this from other 'dialogic' approaches that emphasise particular dialogical pedagogical methods, such as the improvement of classroom talk (cf, for example, Alexander 2008). This dialogic understanding can be simply stated, although it is of course not simple in practice, and does not allow for any easy or once-and-for-all resolution of questions around appropriate curriculum content. The simple statement is that learning in RE consists of a transformative dialogical relationship between student, on the one hand, and religion (or religious content, or religious text) on the other, about some subject matter that is of common interest to them. This account of the constituents of RE learning is consistent in particular with a number of recent attempts to resolve or transcend the AT1/ AT2 distinction between 'learning about' and 'learning from' that has come under heavy fire in recent years (Aldridge 2011; Chater and Erricker 2012; Hella and Wright 2009). Some representation of and engagement with religious texts, communities and concepts will be important here: without an engagement with the genuine or authentic concerns of one's partner, no dialogue can be said to have taken place. This excludes the possibility that RE can be conceived as a personal enquiry devoid of subject content (sometimes offered as a criticism of an emphasis on 'learning from'). By the same token, for a subject matter to be 'shared', it must connect or relate to the interests of the individual student. Whether it be religious education or any other subject, there can be no educational justification for a curriculum that emphasises 'learning about' without any consideration of possibilities for the transformation of the student or opportunities to interrogate the student's own experience in light of curriculum content. The student's 'interests' must, of course, be understood here in light of the development of this term within philosophy of education (cf e.g. Oakeshott 1989). It goes beyond the student's short term or immediate interests and will include matters that the student may not realise to be relevant, or of value, to their own experience without some considerable toil on their own part. This is, of course, why the kind of 'education' we are discussing here involves teachers and does not simply leave students to their own devices. The student's interests will also 
transform as education continues, as it is part of an education to come to realise one's interests in relation to the disciplinary worlds that are offered and opened up along the way.

It is characteristic of the dialogic understanding to view the religions studied as extrinsically valuable - the dialogue with religions is pursued to the extent that it throws up questions that are of mutual concern to both religion and student of religion. What is intrinsically valuable, educationally speaking, is the dialogue. This leads to a further significant point of clarification: although religions (as real social entities) are part of the subject matter of RE, they do not exhaust the subject matter. The study of religion also includes a study of those objects that religions make claims about - divine beings, for example, or ultimate truths. Significant credit must go to Andrew Wright for drawing our attention to this intentionality of the endeavour of RE: the dialogue with religions concerns not only (and in fact, for Wright, not primarily) the sociological or historical nature of religions, but (for Wright) the truth or otherwise of those claims that religions make about transcendent entities or ultimate reality or (I would argue, more broadly) whatever subject matter or referent proves to be the mutual concern of student and religion, or of both participants in the dialogue. So Wright argues that the value of religions as dialogue partners is as the 'primary bearers of transcendent truth claims' (2007: 181). It should be noted at this point that Wright concedes for atheistic perspectives a limited role in the dialogue that is religious education: the naturalist claim, for example, that there is nothing other than a material reality is, in Wright's view, a claim about reality at the ultimate or transcendent level (22), and thus worthy of attention in RE.

An ontologically dialogic account of religious education develops Wright's hermeneutics beyond his own ambitions (Aldridge 2011, and see Aldridge, forthcoming, for a more detailed exposition). In particular it develops Gadamer's recognition, taken over from Collingwood, that there are no 'eternal' or timeless questions, and that subject matter 'emerges' in dialogue. Having a monolithic or 'fixed' understanding of the subject matter at hand will therefore constrain the possibilities for mutual understanding, and ultimately restrict dialogue or stop it in its tracks (see also Collingwood 1978; Gadamer 2004). This has interesting pedagogical implications on two different levels. The first is at the classroom level, as it were, of individual student learning. The moment of understanding is the dialogic achievement of student, teacher and religious content. Since the horizons of understanding of each of these participants will inevitably differ, it follows that the subject matter, or what is 'at issue' between each of these participants, is constituted in the event of learning. Each student is preceded by a different 'effective history', or is perched on a different 'pyramid of past life' (Merleau-Ponty 2002: 457), and therefore, to the extent that he or she 'understands' the content of a particular lesson, understands differently. Elsewhere I have argued, therefore, that the moment of learning for each individual student is in tension with any 'programme of study' or 'scheme of work', since in order to demonstrate progression within subject content a teacher will need to 'move on' to the next item in a methodically predetermined chronology of content which necessarily cannot take into account the indeterminate fusion of horizons that continuously occurs in learning (Aldridge 2013, and forthcoming).

This implication of a dialogic account of learning at the classroom level is pertinent as much for any other curriculum area as for religious education. At the second level, however the level of what might be called, informally, 'the curriculum' - there may be implications that are particularly significant for religious education as a subject area. We should acknowledge here that by 'curriculum' is intended not only policy or guidance documents, 
but also the individual understandings of teachers, schools and departments, the various text books or resources that have become influential, and so on - in fact all of the components that go towards making up the 'commonplaces' of the learner's experience of RE (see Schwab 1973). There are any number of accounts of curriculum that conceive it not so much as a monolithic object but as the dynamic achievement of various evolving entities - academic or disciplinary communities, for example, or the accumulated history of a subject in relation to various understandings of the aims of schooling - and other shifting political forces (Kelly 2009; Beyer and Apple 1998). I need not add, at this point, to the various comprehensive and competent accounts of the historical institutions, policies and forces that have shaped the endeavour that we currently recognise as religious education (see, for recent examples, Chater and Erricker 2012; Conroy et al 2013; Gearon 2014), and the differences in detail between each of these accounts are not our concern here. All of these accounts acknowledge that throughout its evolving history, religious education has concerned itself with different sets of questions at different times. The transition, for example, from a concern primarily with nurturing Christian belief (or at least, nurturing adherence to supposedly shared moral and democratic principles on the grounds of their Christian origins) to a pluralist approach to understanding world faiths more broadly, as codified in the two education reform acts of the twentieth century, is a common feature of these accounts.

A number of contributing factors might explain why religious education is such a contested pedagogical area. There is firstly the unique situation of religious education as a compulsory subject (even up to key stage five in schools that teach to this level) without a single centralised or 'official' curriculum. Add to this the fact that no single academic community or discipline has contributed to the dialogue that is religious education: theology, sociology and philosophy, for example, have all been variously influential. There are regular attempts to connect the content of religious education, particularly around discussions of the specifications of GCSE and A Level Examinations, to the self-understanding of particular academic disciplines - which are consistent with attempts to see these external examinations as gate-keepers to higher education study. However, religious education is unique in being compulsory at key stages four and five, regardless of whether it is chosen or offered as an examination subject. The educational justification for this continued and unusual requirement by implication must go beyond a need to populate degree courses in religious studies or theology with suitably qualified students. Recently the debate about Humanism in religious education has been derailed somewhat by the exclusion of Humanism as a possible option for study from the DfE's consultation document on external examinations in Religious Studies (DfE 2014). This may well be lamentable, but recall that this does not in fact proscribe Humanism from the compulsory provision of religious education that is the concern of this paper.

Contributions to the debate about RE pedagogy (or that constellation of connected questions about what ought to be taught, why, and in what way) can therefore be seen as competing attempts to arrange our thinking about RE around some particular aim, some particular subject matter or content, or some particular question or set of questions. Wright, for example, organises religious education around the ultimate question of the nature of transcendent reality. Felderhof (2012) takes as his starting point the inherited content of religious education - the religious 'life' - and advocates that students should be encouraged to consider what it has to offer them. Other contributions might emphasise the aim of community cohesion, and select content in accordance with how the curriculum might contribute toward achieving that aim (see Janet Orchard's contribution to this issue, or Grimmitt 2010 for further discussion). The appeal of fixing in place a 'starting point' for 
pedagogical discussion is clear: it offers an ordering principle around which we might design or select curriculum content, construct a defence of the importance of religious education in the curriculum, and commend particular approaches to teaching and learning.

No contributor to the debate has wished to defend the status quo; it is characteristic of anyone who takes up the task of writing on RE curriculum and pedagogy to commend new directions for the subject, or at least to warn against the possible loss of some crucial element. Similarly, most acknowledge the historically contingent or 'emergent' nature of the subject that has come down to us; the curriculum might well have been otherwise. Some have suggested total revision through RE's complete rejection or replacement with some other entity (see White 2004, for example, or Tillson 2011), and there is a certain integrity to this kind of approach. Those who rather wish to change or improve the existing entity currently known as religious education have had to identify some element or elements of this evolving entity that are essential to its nature and develop their criticism from there. That such an endeavour is in tension with a historically dynamic picture of the subject is rarely recognised by contributors to the debate, but of the utmost importance, since it matters what we choose as our starting point. Any elements we fix in place concerning any aspect of the aims, content or proper teaching methodology for RE will lock down certain conditions for our answers to other questions, and foreclose other possibilities.

The approach developed in this paper would see religious education at the level of curriculum as the site of a continually evolving dialogue; it would thus recognise fully the historicity of this subject area. It would recognise that the transformative potential of this dialogue, for the students that participate in it, relies on not closing down in advance the paths that the dialogue might take, or the ways that its subject matter might develop and change. I therefore hope to demonstrate that attempts to close out Humanism or other non-religious perspectives as significant contributors to this dialogue are ultimately anti-educational.

\section{An Example of Religious Dialogue}

The argument is best advanced through a consideration of religious dialogue in progress, although one or two caveats are necessary. Firstly, a reminder that rather than commending a certain kind of religious conversation as a pedagogical technique in RE, what is urged in this ontological approach is the need to see RE learning, in all its diverse forms, as having the character of dialogue. It is in this spirit that I offer a fictionalised example of two people in conversation. The second is an acknowledgement that religious dialogue and the dialogue that is religious education have some important differences. Granted, all genuine dialogue is educational, in that participants are united by a mutual aim of better knowing some shared subject matter (see Aldridge, forthcoming). However, something important happens to the ontology of a religious dialogue when we transfer it into a context of schooling; it is precisely this educational implication that I hope will become clear as the discussion continues.

In their introduction to 'Transcendence: Critical Realism and God', Margaret Archer, Andrew Collier and Doug Porpora offer the example of a Christian, Mary, and her atheistic friend Thomas, who come into dialogue about God (Archer et al 2004). Thomas tells Mary that her belief in God is irrational, offering Durkheim, Freud, Marx and Feuerbach's accounts of the human fabrication of the divine story. Mary is not particularly familiar with these accounts, so she goes away and does her reading. When she next meets Thomas, she is able to explain that while these thinkers all offer plausible (though conflicting) accounts of the 
processes by which the idea of God might have been constructed my mankind, none of them 'even bothers to rule out the possibility that people believe in God because there actually is a God that people are experiencing' (17). Mary then introduces Thomas to the 'so-called anthropic coincidences' (18), which leads him to go away and do some more reading of his own. Eventually, we are told, 'Thomas comes across the many-universe theory, and Mary is forced to concede that this is equally plausible an explanation for our universe's appearance of design' (19). The dialogue continues, with the participants 'lovingly challenging each other's claims to the truth' (ibid).

It is unlikely that through this kind of exchange, or through this kind of exchange alone, one or other of these interlocutors will move over into the other's camp; and in any case we know well that religious conversion is not rightly an aim, and hardly ever an outcome, of the endeavour of religious education. Note also that each participant is not required to move to a position of agnosticism even though each cannot conclusively 'prove' his or her position to the other. They are both quite rational in holding their opposing perspectives, provided that they are able to offer reasonable responses to the challenges offered by their partner. However, their shared concern for the subject matter requires that each takes seriously the other's claim to be in possession of the truth. It is the very possibility that their partner in dialogue might have things right that leads each to be so committed to doing their reading, and working hard to understand the other's perspective. Thus each participant in the dialogue opens him or herself up to the possibility of being transformed by the other - and in fact, they are both transformed, in the sense that each is learning or 'growing intellectually' through the dialogue (19). Mary is sufficiently impressed by her reading of Marx, in fact, that she joins the socialist worker's party, and Thomas is forced to concede that his side is not, as he had imagined, the side of science and rational argument: Mary's opposing faith 'is equally rational epistemically for her' (18).

Let us consider, however, the possibility, albeit remote, that one or other participant is so transformed that he or she radically departs from their original standpoint. We have accepted that this transformation is not likely to be effected through this dialogue alone, given the variety of experiential factors that might contribute to the reasonable grounding of each faith perspective; but maybe the dialogue is accompanied by sufficient other small transformations in, let's say, Mary's daily engagement with the world, that renouncing belief in God comes to be a possibility for her. This will not likely result simply from a realisation that the arguments she had been inclined to offer in favour of God's existence do not hold up. Her belief in God will not likely have rested on a single argument or experience (any more than Thomas's naturalism could rest on the possibility of demolishing them), but rather on the consistency of her holistic explanation of the order of things with her daily experience of the world. Some combination of experiences and dialogic interactions, then, might lead Mary to concede more explanatory adequacy (a better 'fit') to Thomas's naturalistic picture of the order of things than her own divine narrative.

I am interested in what would become of the 'subject matter' of the dialogue at this point. Earlier I introduced the dialogue as being 'about God'. In coming no longer to believe that God exists, Mary will need to develop an account of why religion came to occupy such a significant position in society, and even in her own life, if religious truth claims do not correspond to a transcendent reality. She will likely need to develop a new holistic explanation to account for particular events or experiences she has previously been inclined to explain in terms of God. She may very well have new questions about the grounds of meaning, purpose and value in the absence of God, and it is likely that she will bring these 
questions to Thomas so that they can continue their intellectual growth together. So the dialogue continues, but the subject matter has transformed along with the participants: this is no longer a dialogue about God. Note that nothing 'non-realist' is intended by this transformation of the subject matter. God does not come to be or cease to exist in relation to Mary and Thomas's positions on his existence, or their coming to a consensus - but through dialogue, each is transformed in terms of his or her orientation to the world and the concerns that are brought to the dialogue. This is the sense in which subject matter 'emerges', and would in an educational context emerge differently in the engagement between each individual student and the curriculum.

At this point we are well situated to consider the differences between an instance of religious dialogue and the situation of religious education in schools. We firstly recognise how easily this dialogue might have failed to occur. Both participants were motivated by sufficient mutual interest in the subject matter that they were prepared to invest significant time and effort in understanding their partner's contributions. There are any number of occasions, in contrast, where potential partners in dialogue do not find initial common ground, or realise that they are talking at cross-purposes, or decide that they are not prepared to take seriously the possibility of transformation by the differing claims of their partner. The dialogue emerges from the mutual concerns of the participants and continues only to the extent that they find that they have some shared subject matter before them. This is not the case with the 'educational' situation of schooling. Here, an educator must try to keep a dialogue going even though she has essentially pulled students into a dialogue that is already underway. Furthermore, a teacher must plan and establish contours for the future development of the dialogue, without the possibility of full or total knowledge of the horizons of understanding of her students, and therefore of the possible ways in which subject matter might emerge or transform as dialogue continues. The dialogue we have just discussed was able to continue - and was thus educational or constitutive of intellectual growth - because it was aimless; it was able simply to follow or be conducted by the subject matter, whereas the tendency in the context of schooling is for the educational dialogue to be designed.

\section{The Case for Humanism}

It is not the task of this paper to resolve the tension between the aimless and designed aspects of the educational dialogue. Many teachers will no doubt recognise the tactful negotiation of the intended and unintended elements of classroom learning to be the essence and the challenge of the craft of education. However, we are now ready to build the case that, at the curriculum level, attempts to limit in advance the contribution of Humanism and other atheistic perspectives to the RE dialogue are anti-educational.

The first point to make, if we are going to view curriculum in dialogic terms, is that the dialogue is already underway and that Humanism is part of this dialogue. Explicit reference was made to Humanism in both the former non-statutory framework for religious education (QCA 2004) and the recent report on religious education funded by the RE Council (REC 2013). Recent research carried out on behalf of the British Humanist Association found that over three quarters of local agreed syllabuses require some recognition of Humanism in religious education teaching (Watson 2007). Now, these syllabus and other documents do not in any way represent the entirety of what we have argued needs to be considered to be the RE 'curriculum', and there may also be good reason to question the claims of any of the bodies that produced these documents to be adequately representative of 
faith groups or the RE community (Barnes and Felderhof 2014). But in any case it would contradict the spirit of what has been argued so far if we were to concede to any of these bodies or documents the authority to offer a final resolution to matters of debate about the RE curriculum. This observation does nevertheless throw into question the assertion of some critics of the role of Humanism in RE (Barnes in this issue, Barnes and Felderhof 2014) that the burden of proof lies with those who wish to demonstrate that Humanism rightly has a place on the RE curriculum.

All dialogues take place within a tradition, and that tradition, or the context for the possibility of mutual understanding, can evolve and change. So Archer, Collier and Porpora argue for the context in which dialogues about religion can occur: A 'physicalist reductionism' was at once point opposed to religious approaches to the mind-body question, but is now widely believed in philosophical circles to be untenable (2004: 20). However, 'today's more defensible, non-reductive materialism still poses problems for religious worldviews that presuppose a soul as an ontologically distinct, spiritual substance' (21). This has led to sophisticated theological contributions that question whether the soul is an essential element of Christian belief, or a Greek import, and whether Hindu belief needs to maintain a substance-dualism or can make do with a 'dispositional realism'. So, Archer et al argue, 'the dialogue continues', and the requirements for what will constitute a sophisticated contribution develop and change (ibid).

I would like to cautiously suggest an analogous situation in religious education, at one point conceived as nurture into the Christian faith. The change to a non-confessional, multifaith approach in the 1988 education reform act was largely prefigured by the incorporation of world faiths into school teaching from the 1970s and then into ground-breaking agreed syllabuses (most notably that of Birmingham in 1975), potentially in contravention of the spirit of the 1944 act (Cox 1989: 17). I am aware of no scholar on RE in England and Wales now who suggests a complete reversal of this move: it is widely acknowledged that a responsible approach to religious education must take seriously the range of reasonable faith perspectives that exists and not attempt to nurture students into one of these perspectives. It may be that by a similar 'grass roots' transformation we will come to acknowledge that a sophisticated approach to RE must take seriously the existence of perspectives that do not see themselves in religious terms. This is not, contrary to a suggestion that Barnes makes elsewhere in this issue (ref to Barnes in this issue), a matter of apparent 'logical progression', so much as the evolving conditions for the possibility of responsible dialogue. It is not a case of adding ever more perspectives, but rather firstly acknowledging that a dialogue around religion cannot proceed responsibly without admitting the plurality of religious perspectives, and then that it cannot continue without acknowledging the possibility of a non-religious standpoint. It does not inevitably lead to the overcrowding of the curriculum, and consequent crowding out of sophistication, that Barnes is concerned about.

I don't need to push this analogy, however, because even the strongest critics of nonreligious perspectives in religious education acknowledge that they merit some consideration within the curriculum. The real difference is that the dialogic approach would not seek to determine in advance the relevance and relative weight of humanistic perspectives, but would want to leave it to the teacher or other designer to make judgements about the appropriate weight of Humanism in accordance with the unfolding dialogue and requirements for intellectual growth in the specific classroom or context. However, critics of Humanism in RE would limit the amount of Humanism in favour of a focus on religious content, or would 
include non-religious views only as negative challenges to religious truth rather than as objects of study (or partners in dialogue) in their own right (Barnes in this issue).

Let us recall the dialogue between Mary and Thomas, and how the transformative potential of that dialogue, and continued intellectual growth on both sides, had as its ontological condition the possibility (even if it was never actualised) that the dialogue, which was initially around Mary's belief in God, turned out not to be about God, or even about religion, at all. If Mary in her disposition and orientation had not been able to entertain this possibility of the transformation of the subject matter, then she would not have been able to commit herself to the dialogue; there never would have been any real possibility of opening herself to the truth of Thomas's claims.

Such a foreclosure is effected by those who argue that there is no significant place for Humanism in RE. Barnes, for example, argues that religious education offers curriculum space in which children can seriously consider the specific claims of religion. There is little enough time to take more than one religion seriously, Barnes argues, without also having to deal with secular views, which (he argues) are adequately represented elsewhere on the curriculum (Barnes in this issue). So the subject matter of religious education is taken, explicitly and inflexibly, to be religions, and the sui generis nature of their claims (Barnes and Felderhof 2014: 115). This approach to subject matter, I contend, is anti-educational in that although it might be presented as critical - children are urged to seriously consider the value of religions, not to accept that religions are valuable - it has not foreseen, or does not take seriously, the transformation of the subject matter that is entailed when a child says 'no' to religion. Consequently this approach works to create a curriculum space in which this dialogic possibility is restricted. Of course, ontologically speaking, some students will still 'say no', but they will inevitably do so by falling out of dialogue, or by talking at cross purposes.

Another way of looking at this foreclosure of dialogue might be to consider the challenge levelled by critics that Humanism should demonstrate in advance its claim to be a coherent worldview in its own right, rather than a set of negative challenges to theistic belief (Barnes in this issue). Although the idea of holding an explicit 'worldview' is problematic in any case (see Hand 2012), it does not seem fair to assume a priori that Humanists are going to have any more of a problem articulating a worldview than are theists. Furthermore, the need to respond to the charge (levelled not initially by theists, in fact, but by Nietzsche, for one, or Sartre) that Humanists have rejected God but otherwise left intact all of the achievements and inheritances of religion, has been well worked-through and is an essential part of the self-formulation of the Humanist tradition, albeit a necessarily recent development in comparison to the ancient transcendent claims of religious traditions. This only shows up as a problem, however, if we have locked in place a particular understanding of the subject matter of religious education. The Humanist response, in fact, is often an affirmation of the truths that have been inherited from the religious traditions, coupled with an account of how such insights might have come to be attributed to (rather than derived from) some transcendent source. This account is only negative to the extent that the subject matter of religious education has been predetermined to be exclusively religion, God, or the existence of some transcendent reality. As we saw in the case of Mary and Thomas, the Humanist narrative provides a fruitful direction in which the dialogue that is religious education, whatever its starting point, might continue, but it is a direction in which God or transcendent reality would no longer be the primary concern. Humanism only shows up as an incomplete 'alternative' to religious belief if we have not been prepared to entertain the possibility of the 
subject matter's transformation in this way. Wright's claim that religious education concerns itself with the debate about the nature or existence of a transcendent or ultimate reality might prove an excellent way of drawing students into an ongoing dialogue, but it loses its value at the point when perspectives are excluded on the grounds that they are not primarily concerned with the subject matter thus defined.

\section{Some Possible Objections}

This argument does not in large part recapitulate any of the arguments, around inclusion, or toleration, say, that have hitherto been advanced in favour of Humanism on the curriculum (see, for example, Watson 2008). It rather rests on the educational responsibility not to determine in advance the direction of the dialogue that unfolds within the curriculum space of compulsory religious education. I accept here that I have not made the case for Humanism to take up any proportion of an external examination syllabus, and this has not been my aim. Nevertheless, there remain one or two general points of opposition to the allocation of any significant place for Humanism in the RE curriculum to which I feel I should respond.

I recognise that the argument I have presented does not particularly privilege Humanism, but might equally make the case for other 'secular' or non-religious perspectives to be drawn into the dialogue as proves educationally appropriate. This is entirely my intention. This raises the possibility of a slippery slope argument, given the range of possible candidates for secular perspectives that might be on offer. Barnes asks, 'What might pupils "learn from", say a study of National Socialism or Nietzschean "will to power" atheism?' (this issue, draft p. 4). The implication is that if we admit Humanism, we by the same token admit the study of other secular viewpoints that we might consider unsavoury. My response to this is that, yes, we do admit this possibility, given our refusal to determine in advance the range of possible contributors to the ongoing dialogue. But Barnes's question, presented rhetorically, is precisely the one that would inform our decision about curriculum content. It seems likely that educators would more often decide (as indeed they appear to have done) that a study of Humanism has more to contribute to their students' development than a study of National Socialism, but nevertheless one can imagine situations where students have a great deal to 'learn from' a study of National Socialism. This only becomes an unpalatable consequence if we confuse the aim of engaging students in educational dialogue around religious questions with the aim of commending to them some particular stance on religion. We might engage our students in many kinds of fruitful study of National Socialism without intending or anticipating that they will become National Socialists. In state-funded maintained schools we likewise engage students in dialogue with Christianity without the aim of their thereby becoming Christians. Although Barnes laments its 'demise' (draft, p. 16), that particular confessional train has now left the station.

A legal challenge is made, based on the fact that the wording of the 1988 Act requires the teaching of Christianity and the 'other principle religions represented in Great Britain' (Barnes and Felderhof 2014: 111). The RE Council takes this to include secular worldviews (2013: 15), as do the advisory councils of at least three quarters - and on a more recent count mentioned by Barnes possibly as many as 6 out of 7 - local agreed syllabuses. But more or less recent DfE decisions about the place of Humanism in external exam specifications, as well as the lack of any governmental guidance document that confirms this reading, would suggest that this is not perhaps a tenable legal position. I accept that this is disturbing, but would highlight that the inclusion of multi-faith content into local agreed syllabuses prior to 
the 1988 Act would also have been susceptible to a similar challenge, but was ultimately endorsed in legislation. In any case, I am heartened here by the possibility set out by Barnes in his contribution to this journal issue: 'If a strong educational case can be made for the inclusion of a range of non-religious worldviews in religious education, then in my view the law should be changed' (2015: page ref, draft p. 5). We are in agreement on this

Finally, a sort of argument from compensation is offered. The idea, I think, is that a secular view is implicitly presented through the whole school curriculum, and the curriculum space devoted to RE is an opportunity to compensate for this by concentrating on specifically religious views. This compensation can necessarily only be partial, and is even further undermined if secular views must also be included in the RE curriculum. Again, there seems here to be a possible confusion between engaging students in educational debate about the value of religion and commending religious belief to them. Barnes steers close to this, in my view, when he writes that 'just as science education seeks to convey the educational value of science, which in turn presupposes that the content of science has value, so religious education seeks to convey the educational value of religion, predicated on the conviction that the content of religion has value' (2015: draft p. 7). If this is the argument, there seems to be something broken here. If the overall effect of the state-funded curriculum is to commend to students some non-religious belief, this needs to be addressed on the level of the whole curriculum, rather than through the preservation of some sacred curriculum space in which religion can be commended by way of balance or compensation.

There is a problem with the broader academic curriculum that RE needs to address, but Barnes doesn't really get hold of it. The curriculum certainly can become a means through which certain ethical or metaphysical beliefs - Christian, secular or otherwise - can be transmitted without question. Trevor Cooling has made a good case for this, most notably drawing on the work of Carvill and Smith, who argue convincingly that pedagogical resources and practice in the teaching of modern foreign languages have tended to assume an attitude of consumptive capitalism (Cooling 2010; Carvill and Smith 2000). This implicit understanding of language as a means by which we purchase and consume, rather succour or forgive, is one that many Christians might unthinkingly endorse, and many proponents of secular views, not least Humanists, might wish to reject. Religious education does have a particular contribution to make here, as the 'sacred' space in which these assumptions might be explicitly questioned, and from a range of perspectives, including Humanism. The acknowledged lack of this space elsewhere on the curriculum does not, however, amount to any overall commendation through that curriculum of a general or specific non-religious worldview, much less any explicit presentation of a Humanist standpoint.

It might finally be argued that the inclusion of non-religious views into RE blurs its identity with other curriculum priorities, such as Citizenship or SMSC, and weakens its claim to this distinctive and valuable curriculum space. Indeed, it is Cooling's implication, I believe, that rather than being restricted to a particular curriculum area, the dialogue that is religious education should 'spill over' into the wider curriculum space. There is at least one practical problem with this as a proposal. It is unlikely, given the current arrangement of initial teacher education into particular subject specialisms, that teachers currently trained in subject areas other than RE will be adequately equipped to nurture the ongoing dialogue with sufficient sensitivity to religious texts and perspectives. But this is, as I say, a practical problem. In principle, a dialogic approach to religious education would seek to follow the subject matter wherever it led, which could very well mean the erosion of traditional disciplinary boundaries between curriculum areas. If the continuation of this dialogue in an 
educationally valuable way were to necessitate the eventual disappearance of religious education as a discrete curriculum subject, that is a bullet this writer would be prepared to bite.

\section{References}

Aldridge, D (2011) 'What is religious education all about? A hermeneutic reappraisal?', Journal of Beliefs and Values 32:1, 33-45

Aldridge, D (2013) 'The logical Priority of the Question: R G Collingwood, Philosophical Hermeneutics and Enquiry-Based Learning', Journal of Philosophy of Education, 71-85

Aldridge, D (forthcoming) A Hermeneutics of Religious Education, London: Bloomsbury

Alexander, R.J. (2008) Towards Dialogic Teaching: rethinking classroom talk (4th edition), Dialogos.

Archer, M S, Collier, A, Propora, D V (2004) 'Introduction' in Archer, M S, Collier, A, Propora, D V (eds) Transcendence: Critical Realism and God, London and New York: Routledge, 1- 23

\section{Barnes, L P (2015)}

Barnes, L P and Felderhof, M (2014) 'Reviewing the Religious Education Review' Journal of Beliefs and Values, 35:1, 108-117

Beyer, L and Apple, M (1998) 'Values and Politics in the Curriculum' in Beyer and Apple (eds) The Curriculum: Problems, Politics and Possibilities, $2^{\text {nd }}$ edition, Albany: State University of New York Press, 3-17

Chater, M and Erricker, C (2012) Does Religious Education Have a Future? Pedagogical and Policy Prospects, London and Abingdon: Routledge

Collingwood, R G (1978) An Autobiography, Oxford: Oxford University Press

Conroy, J, Lundie, D, Davis, R A, Baumfield, V, Barnes, L P, Gallagher, T, Lowdon, K, Bourque, N, Wenell, K (2013) Does Religious Education Work?, London: Bloomsbury

Cooling, T (2010) Doing God in Education, London: Theos

Cox, E (1989) 'The Years Between' in Cox, E and Cairns, J, Reforming Religious Education: The Religious Clauses of the 1988 Education Reform Act, Kogan Page: Institute of Education, 14-22

DfE (2014) Draft Religious Studies GCSE Content, Department for Education, available at https://www.gov.uk/government/consultations/gcse-and-a-level-reform-religious-studies

Felderhof, M (2012) 'Secular Humanism' in Barnes, L P (ed) Debates in Religious Education, Abingdon: Routledge, 146 - 156 
Gadamer, H-G (2004) Truth and Method, trans Weinsheimer, J and Marshall, D G, London and New York: Continuum [original German publication 1960]

Gearon, L (2014) On Holy Ground: The Theory and Practice of Religious Education, Abingdon and New York: Routledge

Grimmitt, M (ed) (2010) Religious Education and Community Cohesion: An Exploration of Challenges and Opprtunities, Great Wakering: McCrimmon

Hand, M (2012) 'What's in a Worldview? On Trevor Cooling's Doing God in Education' in Oxford Review of Education, 38:5, 527-537

Hella, E and Wright, A (2009) 'Learning 'about' and 'from' religion: phenomenography, the Variation Theory of Learning and religious education in Finland and the UK', British Journal of Religious Education, 31:1, 53-64

Kelly, A (2009) The Curriculum: Theory and Practice, $6^{\text {th }}$ edition, London: SAGE

Merleau-Ponty, M (2002) Phenomenology of Perception, London: Routledge

Oakeshott, M (1989) 'Education, the Engagement and its Frustration', in Fuller, T (ed) The Voice of Liberal Learning: Michael Oakeshott on Education, New Haven and London: Yale University press, $63-94$

\section{Orchard, J (2015)}

QCA (2004) Religious Education in England and Wales: The non-statutory national framework, Qualifications and Curriculum Authority

REC (2013) A Review of Religious Education in England, Religious Education Council of England and Wales, available at http://resubjectreview.recouncil.org.uk/re-review-report

Schwab, J (1973) 'The Practical 3: Translation into Curriculum', The School Review, 81:4, 501-522

Smith, D and Carvill, B (2000) The Gift of the Stranger: Faith, Hospitality and Language Learning (Eerdmans)

Tillson, J (2011) 'In Favour of Ethics Education, Against Religious Education', Journal of Philosophy of Education, 45:4, 675-688

Watson, J (2007) Humanism in Agreed Syllabuses for Religious Education: A Report to the British Humanist Association, available online at http://www.humanism.org.uk/_uploads/documents/Watson-Syllabus-Report.pdf

Watson, J (2008) 'Can children and young people learn from atheism for spiritual development? A response to the National Framework for Religious Education' in British Journal of Religious Education 30:1, 49-58 
White, J (2004) 'Should religious education be a compulsory school subject?', British Journal of Religious Education, 26:2, 151-164

Wright, A (2007) Critical religious education, multiculturalism and the pursuit of truth, Cardiff: University of Wales Press 